\title{
Past Experience of Exclusive Breastfeeding, Early Initiation of Breastfeeding, and Family Support are Important Factors of Exclusive Breastfeeding Practice in Padang Panjang City, Indonesia
}

\section{Melisa Yenti', Mery Ramadani², Dien Gusta Anggraini Nursal², and Rizka Maulida ${ }^{1}$}

${ }^{1}$ Faculty of Public Health, Universitas Indonesia, Depok, Indonesia

${ }^{2}$ Faculty of Public Health, Universitas Andalas, Padang, Indonesia

\section{Abstract}

Based sed on Indonesia Demographic Health Survey (IDHS) in 2012, incidences of

Corresponding Author:

Melisa Yenti

melisa.yenti@ui.ac.id

Received: 21 January 2018

Accepted: 8 April 2018

Published: 17 May 2018

Publishing services provided by Knowledge E

(c) Melisa Yenti et al. This article is distributed under the terms of the Creative Commons

Attribution License, which permits unrestricted use and redistribution provided that the original author and source are credited.

Selection and Peer-review under the responsibility of the 2nd International Meeting of Public Health 2016 Conference Committee. diarrhea and acute respiratory infections in infants aged 0-11 months are 516 and 147 respectively. Additionally, infant mortality rate based on IDHS in 2012 is 32 infant deaths per 1,000 live births. Many efforts are done to overcome these problems, one of which is by exclusive breastfeeding. However, exclusive breastfeeding coverage is still low. According to IDHS in 2012, exclusive breastfeeding for infants is $41.5 \%$. Data from Health Office of Padang Panjang City showed that there is no increase in the coverage of exclusive breastfeeding for the last three years. The aim of this study was to determine the factors associated with exclusive breastfeeding in Padang Panjang City in 2015. A cross-sectional study was conducted between December 2014 to July 2015. The subjects of 152 mothers who had infants aged 6-12 months were selected by using multistage sampling method. Analysis results showed that the significant factors were past exclusive breastfeeding experience with $P R=2.61$ (95\% Cl= 1.4-4.8), early initiation breastfeeding with $P R=1.99$ ( $95 \% \mathrm{Cl}=1.1-3.6)$, and family support with $\mathrm{PR}=2.67(95 \% \mathrm{Cl}=1.1-6.4)$. Past breastfeeding experience is the dominant factor of exclusive breastfeeding with $\mathrm{PR}=3.3(95 \% \mathrm{Cl}=1.5-7.5)$.

Keywords: Exclusive breastfeeding, past exclusive breastfeeding experience, early initiation breastfeeding, family support

\section{INTRODUCTION}

Infants who are fed with other than breast milk have 17 times higher risk to suffer from diarrhea and 3-4 times more likely to suffer from acute respiratory infections (ARI) compared to breast-fed infants (WHO 2000). According to The United Nations 
Children's Fund (UNICEF), exclusive breastfeeding can reduce infant mortality rate in Indonesia and that 30,000 infant deaths in Indonesia and 10 million deaths of children under five in the world each year could be prevented by breastfeeding exclusively for six months from the first hour after birth without providing supplementary food and drink to the infants (Prasetyono 2012).

Based on the results of Indonesia Demographic Health Survey (IDHS) in 2012, the number of diarrhea incidence in infants aged 0-11 months is 516 and the number of ARI incidence is 147 infants. Meanwhile, based on National Basic Health Research 2013, prevalence of pneumonia in infants aged 0-11 months is $2.2 \%$ and the prevalence of diarrhea incidence is 5.5\%. The infant mortality rate in Indonesia based on IDHS in 2012 is 32 infant deaths per 1,000 live births. Based on the National Medium Term Development Plan (NMTDP) 2015-2019 part Health Development and Community Nutrition, one of the targets to be achieved by 2019 is to reduce infant mortality to 24 deaths per 1,000 live births. One of the efforts that can be done to reduce infant mortality is by increasing exclusive breastfeeding (NMTDP of Indonesia 2010).

Exclusive breastfeeding in Indonesia is still low. According to IDHS in 2012 and National Basic Health Research in 2013, exclusive breastfeeding for infants under 6 months old is only $41.5 \%$ and $30.2 \%$ respectively. Data from Health Office of Padang Panjang City in the last three years showed that there was no any increase in the exclusive breastfeeding coverage. The achievements of exclusive breastfeeding in 2012,2013 , and 2014 are $76.6 \%, 75.7 \%$ and $75 \%$, yet have not reached the target of 80\% (Health Office of Padang Panjang City 2014).

Demographically, the Padang Panjang City of is a small area, which covers only \pm 23 $\mathrm{km}^{2}$ equivalent to 2,300 hectares or about $0.05 \%$ of the area of West Sumatra Province (Health Office of Padang Panjang City 2014). Padang Panjang is a small town centered in one place with a population that is not too dense, which makes it a supporting factor for health workers to carry out health interventions easier, including exclusive breastfeeding. In addition, Padang Panjang is also called the City of the Veranda of Mecca where most of the population are muslims and hold strong Islamic principles, such as suggestion to breastfeed the infants until they turn 2 years old.

Many factors affect the success of exclusive breastfeeding. Factors that affect the practice of breastfeeding are individual level which includes attributes of the baby, attributes the mother, and the attributes of both mother and baby; community level which includes the environmental attributes of hospital and health care, home/family environment, work environment, public policy; and community level factors include the attributes of society, culture and economy (Debra 2005). 
Based on the initial survey conducted in 21-22 March 2015 in Padang Panjang to 20 mothers who have infants aged 6-12 months old, there were only seven mothers who breastfeed exclusively. Therefore, this study aimed to examine factors associated with exclusive breastfeeding by mothers in Padang Panjang City in 2015.

\section{METHODS}

Cross-sectional study was conducted in the Padang Panjang City from December 2014 to July 2015. The subjects of this study were mothers of children aged 6-12 months old. Sample size was calculated using sample formula for hypothesis test of 2 proportion Lameshow which resulted 152 subjects and 10\% of drop rate was considered, thus the final sample size calculated was 167 . Inclusion criteria included mothers who were willing to participate in the study and who could communicate well. Mothers of infants aged 0-6 months with severe illness/disease congenital abnormalities, mother was not in the place at the time of the study lasted for 3 days in a row, and mother who had been interviewed in the initial survey were excluded. The sampling was done by multistage sampling. There are two stages of first determining the amount and choosing the cluster, then specifying the subject of research. Variables measured were exclusive breastfeeding status, intention to breastfeed, knowledge of exclusive breastfeeding, past experience of exclusive breastfeeding, early initiation of breastfeeding, supports to exclusively breastfeed from family and health officials. Factors associated with exclusive breastfeeding measured by structured interviews with using a questionnaire. Data were analyzed by using chi-square and multiple logistic regression.

\section{RESULTS}

Table 1 presents the small proportion (22.4\%) of mothers who exclusively breastfed their children, $61.8 \%$ had strong intention to breastfeed, $62.5 \%$ had high knowledge of exclusive breastfeeding, $38.2 \%$ had the past experience of exclusive breastfeeding, $38.8 \%$ had early initiation of breastfeeding, $68.4 \%$ had support for exclusive breastfeeding from family, and $62.5 \%$ had support for exclusive breastfeeding from health officials.

Table 2 presents past experience of exclusive breastfeeding, early initiation of breastfeeding and family support for exclusive breastfeeding showed association with exclusive breastfeeding. 
TABLE 1: Frequency Distribution of Research Variables.

\begin{tabular}{|c|c|c|}
\hline Variable & Frequency (f) & Percentage (\%) \\
\hline \multicolumn{3}{|c|}{ Exclusive Breastfeeding } \\
\hline Yes & 34 & 22.4 \\
\hline No & 118 & 77.6 \\
\hline \multicolumn{3}{|l|}{ Intention } \\
\hline Strong & 94 & 61.8 \\
\hline Less & 58 & 38.2 \\
\hline \multicolumn{3}{|c|}{ Mother's Knowledge } \\
\hline High & 95 & 62.5 \\
\hline Low & 57 & 37.5 \\
\hline \multicolumn{3}{|c|}{$\begin{array}{l}\text { Past Experience of Exclusive } \\
\text { Breastfeeding }\end{array}$} \\
\hline Have & 58 & 38.2 \\
\hline Not Have & 94 & 61.8 \\
\hline \multicolumn{3}{|c|}{ Early Initiation to Breastfeed } \\
\hline $\mathrm{EIB}^{*}$ & 59 & 38.8 \\
\hline Not EIB & 93 & 61.2 \\
\hline \multicolumn{3}{|c|}{ Family Support } \\
\hline High Support & 104 & 68.4 \\
\hline Less Support & 48 & 31.6 \\
\hline \multicolumn{3}{|c|}{ Health Officials' Support } \\
\hline High Support & 95 & 62.5 \\
\hline Less Support & 57 & 37.5 \\
\hline${ }^{\star E} \mathrm{EIB}=$ Early In & & \\
\hline
\end{tabular}

Table 3 presents that multivariate analysis between exclusive breastfeeding and independent variables results found that the most dominant factor exclusive breastfeeding was the past exclusive breastfeeding.

\section{DISCUSSION}

Past exclusive breastfeeding experience, early initiation of breastfeeding, and family support showed association with exclusive breastfeeding. The most dominant factor exclusive breastfeeding was the past breastfeeding experience.

Statistical analysis showed a significant relation between past exclusive breastfeeding experience and exclusive breastfeeding with PR $=2.61(p=0.003)$. Mother who had past exclusive breastfeeding experience were 2.61 times more likely to provide exclusive breastfeeding than mothers who did not have. 
TABLE 2: Relations of Exclusive Breastfeeding and Independent Variables.

\begin{tabular}{|c|c|c|c|c|c|c|c|c|}
\hline \multirow[t]{3}{*}{ Variable } & \multicolumn{6}{|c|}{ Exclusive Breastfeeding } & \multirow{3}{*}{ PR $(95 \% \mathrm{Cl})$} & \multirow{3}{*}{$\begin{array}{c}P \\
\text { value }\end{array}$} \\
\hline & \multicolumn{2}{|c|}{ Yes } & \multicolumn{2}{|c|}{ No } & \multicolumn{2}{|c|}{ Total } & & \\
\hline & $\mathbf{n}$ & $\%$ & $\mathbf{n}$ & $\%$ & $\mathbf{n}$ & $\%$ & & \\
\hline \multicolumn{9}{|l|}{ Intention } \\
\hline Strong & 26 & $27.70 \%$ & 68 & $72.30 \%$ & 94 & $100 \%$ & 2,00 & 0.073 \\
\hline Less & 8 & $13.80 \%$ & 50 & $86.20 \%$ & 58 & $100 \%$ & $(0,9-4,1)$ & \\
\hline Sum & 34 & $22.40 \%$ & 118 & $77.60 \%$ & 152 & $100 \%$ & & \\
\hline \multicolumn{9}{|l|}{$\begin{array}{l}\text { Mother's } \\
\text { Knowledge }\end{array}$} \\
\hline High & 25 & $26.30 \%$ & 70 & $73.70 \%$ & 95 & $100 \%$ & 1,66 & 0.191 \\
\hline Low & 9 & $15.80 \%$ & 48 & $84.20 \%$ & 57 & $100 \%$ & $(0,8-3,3)$ & \\
\hline Sum & 34 & $22.40 \%$ & 118 & $77.60 \%$ & 152 & $100 \%$ & & \\
\hline \multicolumn{9}{|c|}{$\begin{array}{l}\text { Past Experience of } \\
\text { Exclusive } \\
\text { Breastfeeding }\end{array}$} \\
\hline \multicolumn{9}{|c|}{ Have Experience } \\
\hline $\begin{array}{l}\text { Not Have } \\
\text { Experience }\end{array}$ & 21 & $36.20 \%$ & 37 & $63.80 \%$ & 58 & $100 \%$ & 2,61 & 0.003 \\
\hline \multirow[t]{2}{*}{ Sum } & 13 & $13.80 \%$ & 81 & $86.20 \%$ & 94 & $100 \%$ & $(1,4-4,8)$ & \\
\hline & 34 & $22.40 \%$ & 118 & $77.60 \%$ & 152 & $100 \%$ & & \\
\hline \multicolumn{9}{|c|}{$\begin{array}{l}\text { Early Initiation to } \\
\text { Breastfeed }\end{array}$} \\
\hline \multicolumn{9}{|l|}{ EIB* } \\
\hline Not EIB & 19 & $32.20 \%$ & 40 & $67.80 \%$ & 59 & $100 \%$ & 1,99 & 0.034 \\
\hline \multirow[t]{2}{*}{ Sum } & 15 & $16.10 \%$ & 78 & $83.90 \%$ & 93 & $100 \%$ & $(1,1-3,6)$ & \\
\hline & 34 & $22.40 \%$ & 118 & $77.60 \%$ & 152 & $100 \%$ & & \\
\hline \multicolumn{9}{|c|}{ Family Support } \\
\hline Support & 29 & $27.90 \%$ & 75 & $72.10 \%$ & 104 & $100 \%$ & 2,67 & 0.028 \\
\hline Less Support & 5 & $10.70 \%$ & 43 & $89.60 \%$ & 48 & $100 \%$ & $(1,1-6,4)$ & \\
\hline Sum & 34 & $22.40 \%$ & 118 & $77.60 \%$ & 152 & $100 \%$ & & \\
\hline \multicolumn{9}{|c|}{$\begin{array}{l}\text { Health Officials' } \\
\text { Support }\end{array}$} \\
\hline Support & 26 & $27.40 \%$ & 69 & $72.60 \%$ & 95 & $100 \%$ & 1,95 & 0.088 \\
\hline Less Support & 8 & $14.00 \%$ & 49 & $86.00 \%$ & 57 & $100 \%$ & $(0,9-4,0)$ & \\
\hline Sum & 34 & $22.40 \%$ & 118 & $77.60 \%$ & 152 & $100 \%$ & & \\
\hline
\end{tabular}

The similar results to research by Phillips et al. (2011) stated that 70\% of mothers repeated the duration of exclusive breastfeeding of their first child with their second child [14]. Also, similar to research by Dorothy et al. (2015) mothers who exclusively breastfeed will reiterated exclusive breastfeeding and mothers who do not have past 
TABLE 3: Multivariate Analysis between Exclusive Breasfeeding and Independent Variables.

\begin{tabular}{|l|c|c|c|c|}
\hline & P value & PR & \multicolumn{2}{|c|}{$95 \%$ Cl } \\
\hline Variable & & & Lower & Upper \\
\hline $\begin{array}{l}\text { Past Experience of Exclusive } \\
\text { Breastfeeding }\end{array}$ & 0.003 & 3.3 & 1.5 & 7.5 \\
\hline $\begin{array}{l}\text { Early Initiation to Breastfeed } \\
\text { Family Support }\end{array}$ & 0.041 & 2.3 & 1.0 & 5.1 \\
\hline
\end{tabular}

exclusive breastfeeding are likely to stop breastfeeding exclusively at the next child (Dorothy et al. 2015).

Mothers who do not have past exclusive breastfeeding experience or short duration of breastfeeding, they have low confidence and will repeat the same duration, even shorter. The past breastfeeding experience of a mother have more significant role to the next feeding behavior. The success of exclusive breastfeeding at this time determines the success of exclusive breastfeeding for the next child (Dorothy et al. 2015).

Statistical analysis showed that there was significant relation between early initiation of breastfeeding and exclusive breastfeeding PR $=1.99(p=0.034)$. Mothers with early initiation of breastfeeding had the opportunity 1.99 times to exclusively breastfeed than mothers who did not have early initiation of breastfeeding.

These results are similar to research by Ida (2011) that there is significant relation between early initiation of breastfeeding and exclusive breastfeeding PR $=2.36(P=$ 0.024). Mothers with early initiation of breastfeeding have the opportunity 2.36 times to exclusively breastfeed than mothers who do not have early initiation of breastfeeding [6].

One of factors that influence the success of exclusive breastfeeding is early initiation of breastfeeding. One key to success is role of health officials that can facilitate the success of early initiation breastfeeding. By the early initiation to breastfeed, mother is more confident to continue providing her breast milk and she will not feel the need to provide food/drink anything to the baby because the baby can be comfortably breastfed [4].

Statistical analysis showed that there was significant relation between family support and exclusive breastfeeding with $P R=2.67(P=0.028)$. Mothers who got the support from family to exclusively breastfeed were 2.67 times more likely to exclusively breastfeed than mothers who got the low support.

These results are similar to research by Ida (2011) that there is significant relation between family support and exclusive breastfeeding with $P R=4.11(p=0.002)$. 
Mothers who got family support for breastfeeding have the opportunity 4.11 times to exclusively breastfeed than mothers who got the low support [6].

Support from family members, especially from the father was very important in exclusive breastfeeding. The not supportive behavior and negative attitudes from family can reduce the duration of breastfeeding [11].

Based on multivariate analysis, dominant variables associated with exclusive breastfeeding were past exclusive breastfeeding experience with $P R=3.3$ ( $P$ value $=0.003$ ). Mothers who had past exclusive breastfeeding experience had a 3.3 times greater chance to exclusively breastfeed their infants.

Similar to research by Nagi et al. (2001), compared to mother who do not have past exclusive breastfeeding experience, mother who exclusively breastfed her first infant is more likely to exclusively breastfeed her second baby, too [9].

Past exclusive breastfeeding experience, breastfeeding the first baby, and knowledge about the benefits of breastfeeding affect on the mother's decision to breastfeed her baby or not. The more number of baby that a mother has, the breastfeeding behavior will be better because of the breastfeeding experience and the experience can gain knowledge about breastfeeding [13].

\section{CONCLUSION AND RECOMMENDATION}

The most important factor of exclusive breastfeeding practice in Padang Panjang City in 2015 is the past exclusive breastfeeding experience. All mothers, especially mothers who get pregnant for the first time are expectedly to prepare themselves physically and mentally to be able to breastfeed exclusively later as it can affect the next lactation.

\section{ACKNOWLEDGMENT}

Many thanks to lecturers for the guidance, mothers who participate in this study, the integrated health care "Posyandu" cadres and primary health care "Puskesmas" staff in Padang Panjang City.

\section{References}

[1] Bai, D. L., Fong, D. Y. T., \& Tarrant, M. (2015). Previous Breastfeeding Experience And Duration of Any And Exclusive Breastfeeding Among Multiparous Mothers. Birth, 
42(1), 70-77.

[2] Dasar, R. K. (2010). Badan Penelitian Dan Pengembangan Kesehatan. Jakarta: Kementerian Kesehatan.

[3] Data, P, \& RI, I. K. K. (2014). Situasi dan Analisis ASI Eksklusif. Jakarta: Kementerian Kesehatan RI.

[4] Fikawati, S., \& Syafiq, A. (2009). Penyebab Keberhasilan Dan Kegagalan Praktik Pemberian ASI Eksklusif. Kesmas: Jurnal Kesehatan Masyarakat Nasional, 4(3), 120131.

[5] Hector, D., King, L., Webb, K., \& Heywood, P. (2005). Factors Affecting Breastfeeding Practices. Applying a Conceptual Framework. New South Wales public health bulletin, 16(4), 52-55.

[6] Ida. (2012). Faktor-faktor Yang Berhubungan Dengan Pemberian ASI Eksklusif 6 Bulan Di Wilayah Kerja Puskesmas Kemiri Muka Koto Depok Tahun 2011. Universitas Indonesia.

[7] Indonesia, K. K. R. (2013). Riset kesehatan dasar 2013. Jakarta: Badan Litbangkes.

[8] Kemenkes, R. I. (2012). Rencana Aksi Akselerasi Pemberian ASI Eksklusif 2012-2014. Kemenkes RI.

[9] Nagy, E., Orvos, H., Pal, A., Kovacs, L., \& Loveland, K. (2001). Breastfeeding duration and previous breastfeeding experience. Acto Paediatrica, 90(1), 51-56.

[10] Nasional, B. P. P. (2010). Rencana Pembangunan Jangka Menengah Nasional (RPJMN) 2010-2014.

[11] Nugroho, T. (2011). Asi Dan Tumor Payudara. Yogyakarta: Nuha Medika.

[12] Panjang, D. K. K.P (2014). Profil Kesehatan Koto Padang tahun 2012-2014.

[13] Perinasia. (1994). Melindungi, Meningkatkan dan Mendukung Menyusui. Jakarta: Bina Rupa Akasara.

[14] Phillips, G., Brett, K., \& Mendola, P. (2011). Previous breastfeeding practices and duration of exclusive breastfeeding in the United States. Maternal and child health journal, 15(8), 1210-1216

[15] Prasetyono, D. S (2009). Buku pintar ASI eksklusif. Cetakan pertama. Jogjakarta: Diva Press (Anggota IKAPI).

[16] Statistik, B. P. (2007). Survei Demografi Kesehaton Indonesia. Jakarta: BPS 